\title{
The Prudent Investor Rule and Trust Asset Allocation: An Empirical Analysis
}

\section{Citation}

Robert H. Sitkoff \& Max Schanzenbach, The Prudent Investor Rule and Trust Asset Allocation: An Empirical Analysis, 35 ACTEC J. 314 (2010).

\section{Published Version}

http://www.actec.org/resources/publications/notes/PDFNotes/ACTEC_Journal_Spring_10.pdf

\section{Permanent link}

http://nrs.harvard.edu/urn-3:HUL.InstRepos:15032762

\section{Terms of Use}

This article was downloaded from Harvard University's DASH repository, and is made available under the terms and conditions applicable to Other Posted Material, as set forth at http:// nrs.harvard.edu/urn-3:HUL.InstRepos:dash.current.terms-of-use\#LAA

\section{Share Your Story}

The Harvard community has made this article openly available.

Please share how this access benefits you. Submit a story.

\section{Accessibility}




\title{
HARVARD
}

JOHN M. OLIN CENTER FOR LAW, ECONOMICS, AND BUSINESS

\author{
THE PRUDENT INVESTOR RULE AND \\ TRUST ASSET ALLOCATION: AN \\ EMPIRICAL ANALYSIS
}

Max M. Schanzenbach and Robert H. Sitkoff

Discussion Paper No. 668

$05 / 2010$

Harvard Law School

Cambridge, MA 02138

This paper can be downloaded without charge from:

The Harvard John M. Olin Discussion Paper Series:

http://www.law.harvard.edu/programs/olin_center/

The Social Science Research Network Electronic Paper Collection: http://ssrn.com/abstract=1551470 


\title{
The Prudent Investor Rule and Trust Asset Allocation: An Empirical Analysis*
}

\author{
by Max M. Schanzenbach and \\ Robert H. Sitkoff
}

\begin{abstract}
This article reports the results of an empirical study of the effect of the new prudent investor rule on asset allocation by institutional trustees. Using federal banking data spanning 1986 through 1997, the authors find that, after adoption of the new prudent investor rule, institutional trustees held about 1.5 to 4.5 percentage points more stock at the expense of "safe" investments. This shift to stock amounts to a 3 to 10 percent increase in stock holdings and accounts for roughly 10 to 30 percent of the over-all increase in stock holdings in the period under study. The authors conclude that the adoption of the new prudent investor rule had a significant effect on trust asset allocation.
\end{abstract}

Published: 35 ACTEC Journal 314 (2010) 


\title{
The Prudent Investor Rule and Trust Asset Allocation: An Empirical Analysis*
}

\author{
by Max M. Schanzenbach, Chicago, Illinois, ** and \\ Robert H. Sitkoff, Cambridge, Massachusetts***
}

Editor's Synopsis: This article reports the results of an empirical study of the effect of the new prudent investor rule on asset allocation by institutional trustees. Using federal banking data spanning 1986 through 1997, the authors find that, after adoption of the new prudent investor rule, institutional trustees held about 1.5 to 4.5 percentage points more stock at the expense of "safe" investments. This shift to stock amounts to a 3 to 10 percent increase in stock holdings and accounts for roughly 10 to 30 percent of the overall increase in stock holdings in the period under study. The authors conclude that the adoption of the new prudent investor rule had a significant effect on trust asset allocation.

\section{Introduction}

\subsection{The Quiet Revolution in American Trust Law}

A quiet revolution in American trust law is upon us. Traditional rules, unchanged for decades, have been revised substantially or, in some cases, reversed. The law pertaining to trust investment, including prudence, diversification, and accounting for principal and income; perpetuities; asset protec- tion trusts; fiduciary obligation in revocable trusts; trustees' powers; direction of trustees and trust protectors; delegation by trustees; modification, termination, and trustee removal; settlor standing; noncharitable purpose trusts; beneficiaries' rights to information; and business trusts, among others, has been updated or rewritten altogether. ${ }^{1}$ Cases involving facts that are indistinguishable from those of precedents fewer than twenty-years old are yielding opposite outcomes. ${ }^{2}$

Some of the new trust law has been produced top-down by the American Law Institute and the Uniform Law Commission, through the Restatements and Uniform Acts. ${ }^{3}$ The top-down process is typified by academic reporters (drafters) and advisors working in concert with practitioner representatives from the American College of Trust and Estate Counsel and the Section on Real Property, Trusts, and Estates of the American Bar Association. In general, the top-down reforms are designed to update the law in view of the transformation of the irrevocable trust into a management device for financial assets, ${ }^{4}$ the increasingly common use of the revocable trust as a will substitute, ${ }^{5}$ and the rise of the statutory business trust. ${ }^{6}$
* This article expands on a portion of Professor Sitkoff's Joseph Trachtman Memorial Lecture, "The Quiet Revolution in American Trust Law: An Empirical Assessment," presented to the American College of Trust and Estate Counsel in Rancho Mirage, California, on March 7, 2009. The article draws on Max M. Schanzenbach \& Robert H. Sitkoff, Did Reform of Prudent Trust Investment Laws Change Trust Portfolio Allocation?, 50 J.L. \& Econ. 681 (2007), and Jesse Dukeminier, Robert H. Sitkoff \& JAMES Lindgren, Wills, Trusts, AND Estates (8th ed. 2009). This work is part of an ongoing series of empirical studies that will form the core of a book by Professors Schanzenbach and Sitkoff, Lawyers, Banks, and Money: The Quiet Revolution in AMERICAN TRUST LAW, to be published by Yale University Press. Professor Sitkoff previewed several themes of that book, a few of which are touched on in this article, in his Trachtman Lecture.

** Benjamin Mazur Professor of Law, Northwestern University, email: m-schanzenbach@law.northwestern.edu.

*** John L. Gray Professor of Law, Harvard University, email: rsitkoff@law.harvard.edu.

For a sampling, see JESSE DUKEMINIER, Robert H. SITKOFF \& James Lindgren, Wills, Trusts, AND Estates 398-407, 585$588,624-638,644-652,656-658,659-660,691-702,717-725,730$ -
736, 743-745, 785-786, 905-917 (8th ed. 2009).

Compare In re Trust of Stuchell, 801 P.2d 852 (Or. App. 1990) (refusing deviation toward a special needs trust, in spite of a disabled later-born beneficiary, following Restatement (Second) of Trusts $§ 167$ (1959)), with In re Riddell, 157 P.3d 888 (Wash. App. 2007) (allowing deviation toward a special needs trust, in view of a disabled later-born beneficiary, following Restatement (Third) of Trusts $§ 66$ (2007)). See Dukeminier, SitKoff \& Lindgren, supra note 1 , at 643-649.

See Edward C. Halbach, Jr., Uniform Acts, Restatements, and Trends in American Trust Law at Century's End, 88 CAL. L. REV. 1877 (2000).

${ }^{4}$ See John H. Langbein, Rise of the Management Trust, TR. \& EsT., Oct. 2004, at 52.

See Alan Newman, Revocable Trusts and the Law of Wills: An Imperfect Fit, 43 ReAL PROP., TR. \& EST. L.J. 523 (2008); John H. Langbein, The Nonprobate Revolution and the Future of the Law of Succession, 97 Harv. L. Rev. 1108, 1113 (1984).

${ }^{6}$ See the Prefatory Note to the Uniform Statutory Trust ENTITY ACT (2009). See also Robert H. Sitkoff, Trust as "Uncorporation”: A Research Agenda, 2005 U. ILL. L. REV. 31. 
Other major changes to the trust law canon have been bottom-up, driven by local lawyers and bankers in response to the increasingly national scope of the competition for trust business. These reforms are implemented through the lobbying efforts of state bar and bankers' associations, spurred on by a desire to attract or retain trust business. ${ }^{7}$ As a consequence, the bottom-up reforms tend to promote dead hand control, reflecting the commercial necessity of appealing to apparent donor preferences. ${ }^{8}$

These dual modes of law reform, which operate either in tandem or in opposition depending on the issue, have produced a thoroughly revised and increasingly statutory trust law. ${ }^{9}$ Today the state legislatures, not the state courts, are the makers of American trust law. The new statutory trust law is clearer, an important development given the national character of modern trust practice and the lack of deep case law precedent in many states. ${ }^{10}$ But being statutory, the new law is also less supple and may prove harder to change.

In an ongoing series of articles, we have undertaken to assess empirically the effects of the quiet revolution in American trust law. For example, we have studied the effect of the repeal of the Rule Against Perpetuities, finding that there is a vigorous competition for trust funds. The situs of over $\$ 100$ billion in trust assets has been influenced by the recognition of perpetual trusts. ${ }^{11}$ Further study of perpetual trusts and other reforms, both top-down and bottom-up, is in progress, as is a more general study of the political economy of American trust law reform. Ultimately these projects will be synthesized into a book, Lawyers, Banks, and Money: The Quiet Revolution in American Trust Law, to be published by Yale University Press.

In this article, we summarize our findings to date on the effect of the new prudent investor rule on asset allocation in noncommercial trusts. ${ }^{12}$ Perhaps the quintessential top-down reform, the new prudent investor rule was presaged in the scholarly literature and is solidly grounded in modern portfolio theory. But the rule took firm hold only after the promulgation of the Restatement (Third) of Trusts in 1992 and the Uniform Prudent Investor Act in 1994. Today some version of the new prudent investor rule is the law in all states.

\subsection{Summary Statistics}

Although a private trust arises from private agreement without the need for a filing with the state, there are nonetheless public data on trust usage in donative transfers, chiefly from two sources. First, federal law requires banks and other trust institutions that are part of the Federal Reserve System to make annual reports of their trust holdings. These reports indicate roughly $\$ 760$ billion held in roughly 1.25 million private and charitable trust accounts as of year-end 2006. These eye-popping figures necessarily understate the donative trust business because they exclude all trusts for which the trustee is not an institution in the Federal Reserve System.

Second, data on donative trust usage can be assembled from trust income tax returns. Trustees of "simple" and "complex" trusts, which are tax terms of art, must file a federal tax return, Form 1041, in each year that the trust earns income. ${ }^{13}$ In filing-year 2007, the Internal Revenue Service received more than 2 million such returns reporting $\$ 142.5$ billion in gross income, $\$ 3.7$ billion in fiduciary fees paid, and $\$ 1.6$ billion in attorney, accountant, and other professional services fees paid. These figures exclude trusts, such as revocable trusts, that are not simple or complex under the tax code, hence these figures too understate trust usage in practice.

These data, patchy though they may be, show that state trust investment law governs the investment of
See, e.g., Stewart E. Sterk, Jurisdictional Competition to Abolish the Rule Against Perpetuities: R.I.P. for the R.A.P., 24 CARdozo L. ReV. 2097 (2003). In Professor Dobris' words, "When the bankers want something, they get it." Joel C. Dobris, Changes in the Role and the Form of the Trust at the New Millennium, or, We Don't Have To Think of England Anymore, 62 ALB. L. REV. 543, 572 (1998).

8 See, e.g., Joshua C. Tate, Perpetual Trusts and the Settlor's Intent, 53 U. Kan. L. REV. 595 (2005).

9 See John H. Langbein, Why Did Trust Law Become Statute Law in the United States?, 58 AlA. L. Rev. 1069 (2007); DuKemINIER, SITKOFF \& LINDGREN, supra note 1, at 544-547.

${ }_{10}$ See Langbein, supra note 4, at 56-57.

${ }^{11}$ See Robert H. Sitkoff \& Max M. Schanzenbach, Perpetuities, Taxes, and Asset Protection: An Empirical Assessment of the Jurisdictional Competition for Trust Funds, in 42 ANNUAL HeCKERLING INSTI- tute on Estate Planning at 14-1 (Tina Portando ed., Lexis-Nexis, 2008); Max M. Schanzenbach \& Robert H. Sitkoff, Perpetuities or Taxes? Explaining the Rise of the Perpetual Trust, 27 CARDOzO L. REv. 2465 (2006); Robert H. Sitkoff \& Max M. Schanzenbach, Jurisdictional Competition for Trust Funds: An Empirical Analysis of Perpetuities and Taxes, 115 YALE L.J. 356 (2005). See also Rachel Emma Silverman, Looser Trust Laws Lure $\$ 100$ Billion, WALL ST. J., Feb. 16, 2005, at D1 (reporting our findings).

${ }^{12}$ For our more formal presentation, see Max M. Schanzenbach \& Robert H. Sitkoff, Did Reform of Prudent Trust Investment Laws Change Trust Portfolio Allocation?, 50 J.L. \& ECON. 681 (2007).

${ }_{13}$ See Jeffrey G. Sherman, All You Really Need To Know About Subchapter J You Learned from This Article, 63 Mo. L. REV. 1 (1998). 
substantial sums of money. ${ }^{14}$ Yet the effect of the new prudent investor rule on trust investment practices has been largely unstudied..$^{15}$

\subsection{Prudent Trust Investment Law}

"How do you make a small fortune? Give a bank a large one to manage in trust." ${ }^{, 16}$ So goes an old saw about the banking industry that reflects long experience with risk-averse, conservative trust investing by institutional trustees operating under the prudent man rule of trust investment law. The prudent man rule favored "safe" investments such as government bonds and disfavored speculation in stock, and under the rule the courts assessed the prudence of each investment in isolation rather than in the context of the portfolio as a whole.

Over the last 25 years, all states have replaced the old prudent man rule with the new prudent investor rule. Drawing on the teachings of modern portfolio theory, the new prudent investor rule directs the trustee to invest on the basis of risk and return objectives reasonably suited to the trust and instructs courts to review the prudence of individual investments not in isolation but in the context of the trust portfolio as a whole. ${ }^{17}$ The new prudent investor rule thus abolishes all categorical restrictions on permissible types of investments and clearly rejects the old law's hostility to investment in stock. ${ }^{18}$ The question thus arises: Has the new law affected asset allocation in noncommercial trusts?

Making use of state- and institution-level panel data of trust assets held by institutions in the Federal
Reserve System between 1986 and $1997,{ }^{19}$ we examined the effect of the new prudent investor rule on trust asset allocation. In the period under study, 35 states adopted the new rule. ${ }^{20}$ We find that after a state's adoption of the prudent investor rule, reporting trust institutions held about 1.5 to 4.5 percentage points more stock at the expense of "safe" investments, ${ }^{21}$ suggesting movement outward on the risk and return curve. This shift to stock amounts to a 3 to 10 percent increase in stock holdings and accounts for roughly 10 to 30 percent of the overall increase in stock holdings in the period under study. We provide some evidence that the rest of the increase is attributable to stock market appreciation.

Even though trust investment laws are nominally default rules, we conclude that such rules affect trust portfolio allocation in practice. Further, by showing that trustees are sensitive to changes in trust fiduciary law, our findings imply that the fiduciary obligation is a viable means of trust governance.

\subsection{Organization}

The remainder of this article is organized as follows. Section 2 motivates the empirical analysis by surveying the law and economics of trust investment. Section 3 explains our research design, the nature of our sample data, and our identification strategies. Section 4 presents our findings, first with a graphical analysis and second with a summary of our econometric analysis. For accessibility, in Sections 3 and 4 we
${ }^{14}$ In view of the increasing use of perpetual trusts and the growing popularity of the inter vivos revocable trust as a mode of nonprobate transfer, the volume of investment capital managed by trustees is likely to grow further. Moreover, UNIFORM PRUDENT MANAGEMENT OF Institutional Funds ACT $\S 3$ (2006) applies the prudent investor rule to charities organized as nonprofit corporations (charities organized as trusts are covered directly by state trust investment law).

15 The prior literature is thin. In Martin D. Begleiter, Does the Prudent Investor Need the Uniform Prudent Investor Act-An Empirical Study of Trust Investment Practices, 51 ME. L. REv. 27 (1999), the author reports the results of his survey of 239 banking institutions in Iowa. Of the 61 institutions that replied, a substantial majority indicated that they employed risk/return analysis in making trust investments and that the new prudent investor rule did not flatly prohibit specific investments. Begleiter did not undertake a before-and-after comparison.

In Kristine Watson Hankins, Mark J. Flannery \& Mahendrarajah Nimalendran, The Effect of Fiduciary Standards on Institutions' Preference for Dividend-Paying Stocks, 37 FIN. MGMT. 647 (2008), published after our 2007 study, the authors examine the effect of prudent trust investment laws on the preference for dividend-paying stocks among institutional investors such as insurance companies and bank trust departments. Based on SEC filings covering the period 1990 to 2000 , they find that such institutions increased their holdings in non-dividend-paying stocks after a state's adoption of the new prudent investor law. However, their data do not distinguish between personal trusts and other funds not formally covered by state prudent investor rules, such as Employee Retirement Income Security Act of 1974 (ERISA) benefit funds. By contrast, our data isolate actively-managed personal trust funds from other institutional holdings and more closely align those funds with the applicable state law; we exclude principal and income reform, which potentially affects asset allocation and is likely to affect preference for dividend-paying stocks; and in some specifications we use ERISA funds, which are governed by federal law, as a control group.

${ }^{16}$ Jesse Dukeminier \& James E. Krier, The Rise of the Perpetual Trust, 50 UCLA L. REV. 1303, 1335 (2003).

${ }_{17}$ Uniform PRUdent InVestor ACT (UPIA) § 2(b) (1994); RESTATEMENT (THIRD) OF TRUSTS $§$ 90(a) (2007).

${ }_{18}$ UPIA $\S 2(\mathrm{e})$ (1994); RESTATEMENT (THIRD) OF TRUSTS $\S 90$, cmt. 1 (2007).

${ }_{19}$ The nature and sources of our data are detailed in Section 3.1 .

${ }^{20}$ Nine of those 35 adoptions, however, came in 1997, the last year of the study. See Figure 2 and Appendix.

${ }^{21}$ The reasons for studying percentage of stock holdings and the meaning of "safe" investments are detailed in Section 3. 
summarize rather than include our econometric analysis, which is readily available elsewhere. ${ }^{22}$ Section 5 concludes by considering several doctrinal and policy implications of our findings and points to further research questions.

\section{The Law and Economics of Trust Investment}

\subsection{Fiduciary Administration}

A trust is a fiduciary relationship in which the trustee holds legal title to specific property, entrusted to him or her by the settlor, and manages that property for the benefit of one or more beneficiaries. The trust therefore separates beneficial ownership (the beneficiaries) and control (the trustee), interposing a fiduciary between the beneficiaries and the trust property. ${ }^{23}$

In recognition of the need for flexible management to account for changing market conditions and the evolving needs of the beneficiaries, the modern law gives the trustee expansive powers. But with broad trustee empowerment comes the need to safeguard the beneficiaries from mismanagement and misappropriation. Enter the fiduciary obligation. ${ }^{24}$ Trust law supplies a set of fiduciary rules, largely default but with a mandatory core, ${ }^{25}$ that prescribe the trustee's level of care (the duty of prudence) and proscribe misappropriation (the duty of loyalty). Such terms are open-ended standards that are enforced through ex post litigation, in effect an after-the-fact judicial completion of the trust agreement. A beneficiary who believes that the trustee acted disloyally or imprudently may sue the trustee for breach of trust.

Because trust default law makes it difficult for the beneficiary to remove the trustee, and because the beneficiary's interest is typically inalienable (that is, there is no market for trust control), the threat of fiduciary litiga-

${ }^{22}$ Readers interested in our formal econometric analysis should consult Schanzenbach \& Sitkoff, supra note 12, at 692-707.

${ }^{23}$ See Robert H. Sitkoff, An Agency Costs Theory of Trust Law, 89 CORNELL L. REV. 621 (2004).

${ }^{24}$ See Langbein, supra note 4, at 54.

${ }^{25}$ See McNeil v. McNeil, 798 A.2d 503, 509 (Del. 2002) (“A trust in which there is no legally binding obligation on a trustee is a trust in name only and more in the nature of an absolute estate or fee simple grant of property."). See also John H. Langbein, Mandatory Rules in the Law of Trusts, 98 Nw. U. L. REV. 1105 (2004); Melanie B. Leslie, Trusting Trustees: Fiduciary Duties and the Limits of Default Rules, 94 GEO. L.J. 67 (2005).

${ }^{26}$ See Sitkoff supra note 23; Robert H. Sitkoff, Trust Law, Corporate Law, and Capital Market Efficiency, 28 J. CORP. L. 565 (2003). The paramount role of fiduciary law in minimizing agency costs in trust governance explains the traditional rule that a private trust must be for the benefit of an ascertainable beneficiary. tion is the primary force for aligning the interests of the trustee and the beneficiary-that is, for minimizing agency costs in the modern trust relationship. ${ }^{26}$ With respect to managing the trust's assets, unless the settlor provides otherwise, the trustee's fiduciary duty of prudence is defined by the default rules of the state's prudent trust investment laws.

\subsection{The Prudent Man Rule}

After the South Sea Bubble burst in 1720, the English Court of Chancery developed a list of presumptively proper investments for trustees. These "legal lists," which later were widely adopted in the United States, generally favored investment in government bonds and first mortgages and proscribed investment in equities. ${ }^{27}$

In the seminal case of Harvard College $v$. Amory ${ }^{28}$ the Massachusetts Supreme Judicial Court rejected the legal list and adopted what came to be known as the prudent man rule. The court held that the trustee must "observe how men of prudence, discretion and intelligence manage their own affairs, not in regard to speculation, but in regard to the permanent disposition of their funds, considering the probable income, as well as the probable safety of the capital to be invested." ${ }^{29}$ Nudged along by the American Bankers Association, which in the 1940s sponsored a model statute codifying Amory, most states abandoned their legal lists for the Amory prudent man rule..$^{30}$

In spite of the flexibility of the open-ended prudent man formulation, the influence of the rigid legal lists continued. Courts generalized rules from the specific facts of prior cases. "Specific case results ... thereby became crystallized into specific subrules prescribing the types and characteristics of permissible

Restatement (THIRD) OF TRUsTs $\S 44$ (2003). Requiring an ascertainable beneficiary ensures that there is someone with an economic incentive to enforce the trust.

${ }^{27}$ See John H. Langbein \& Richard A. Posner, Market Funds and Trust-Investment Law, 1976 ABF Res. J. 1, 3-4 (1976); Lawrence M. Friedman, The Dynastic Trust, 73 YALE L.J. 547, 567-568 (1964). For a specific example, see King v. Talbot, 40 N.Y. 76 (1869), which restricted trust investment to government bonds and first mortgages and forbade investment in corporate securities.

2826 Mass. 446 (1830).

${ }^{29}$ Id. at 469.

${ }^{30}$ The model prudent man rule statute and the role of the banking lobby are discussed in Langbein and Posner, supra note 27, at 5, and Mayo A. Shattuck, The Development of the Prudent Man Rule for Fiduciary Investment in the United States in the Twentieth Century, 12 OнIо ST. L.J. 491, 499-504, 508-509 (1951). 
investments for trustees." ${ }^{11}$ The prudent man rule devolved into a highly constrained default, encrusted with a host of subrules whereby "broad categories of investments and techniques often came to be classified as 'speculative' and thus as imprudent per se." 32

The Restatement (Second) of Trusts, published in 1959 , took the position that "[o]rdinarily it is proper for a trustee to invest in ... bonds of the United States or of the State or of municipalities, in first mortgages on land, or in corporate bonds.. ${ }^{33}$ However, investing in "speculative" stock, ${ }^{34}$ buying securities on margin, or buying discounted bonds was presumptively improper. $^{35}$

The old law's preoccupation with safety and speculation invited what psychologists and behavioral economists call hindsight bias in the form of after-thefact "searches for evidence that investments were too risky." ${ }^{36}$ If a higher risk investment did not pay off, the trustee faced potential liability for imprudently speculating in stock. ${ }^{37}$ Worse still, the courts assessed the prudence of each investment in isolation rather than in the context of the portfolio as a whole. This practice exposed the trustee to liability for a decline in the value of one stock even if that stock was part of a welldiversified portfolio suited to the purpose of the trust and the risk tolerance of the beneficiaries.

At the same time, judicial enforcement of language in the trust instrument modifying the prudent man rule, or purporting to release the trustee from the rule altogether, was at best uncertain. Neither a specific empowerment in the trust instrument to make a particular investment nor a broad exculpation clause insulated the trustee from judicial review. ${ }^{38}$ Not surprisingly, prior studies have found bank trust departments to be among the most conservative of institutional investors. ${ }^{39}$

\subsection{The Prudent Investor Rule}

In the latter part of the twentieth century, scholars and practitioners familiar with modern portfolio theory began calling for reform of the prudent man rule. ${ }^{40}$ As the critics rightly noted, investments cannot be characterized as "safe" or "speculative" in abstract
${ }^{31}$ Restatement (Third) of Trusts at p. 288 (2007) (Introductory Note to Chapter 17).

${ }^{32} I d$.

33 Restatement (Second) of Trusts $§ 227$, cmt. f (1959).

${ }^{34}$ Defined to include stock in any company other than one "with regular earnings and paying regular dividends which may reasonably be expected to continue." Id. at $\mathrm{cmt}$. $\mathrm{m}$.

${ }^{35}$ Id. at cmts. f \& $\mathrm{m}$.

36 Jeffrey J. Rachlinski, Heuristics and Biases in the Courts: Ignorance or Adaptation?, 79 OR. L. REV. 61, 79-80 (2000). In re Chamberlain's Estate, 156 A. 42, 43 (1931), is an egregious example: It was common knowledge, not only amongst bankers and trust companies, but the general public as well, that the stock market condition [in August 1929] was an unhealthy one, that values were very much inflated, and that a crash was almost sure to occur. In view of this fact, I think it was the duty of the executors to dispose of these stocks immediately upon their qualification as executors.

Common knowledge indeed! Query whether the judge had been selling short in the months before the crash. People who know that the market will crash tomorrow will sell today. If it had been common knowledge in August 1929 that a crash was looming, then the crash would have started in August, not October.

${ }_{37}$ See, e.g., First Alabama Bank of Montgomery v. Martin, 425 So. 2d 415, 427 (Ala. 1983), which held that investment in a set of stocks that underperformed was imprudent "speculation" because the trustee had intended to sell them after appreciation. See also Rachlinski, supra note 36, at 79-81 (collecting cases).

${ }^{38}$ On exculpation clauses, see DuKEMINIER, SitKofF \& LiNDGREN, supra note 1, at 607-608. On modifying the default duty of prudence in trust investment, see id. at 717-720. The legal principle is that the trustee's exercise or nonexercise of a power, even one specifically granted by the trust instrument, is subject to the trustee's fiduciary obligations to the beneficiaries. In the words of the Restatement, "the fact that an investment is permitted does not relieve the trustee of the fundamental duty to act with prudence. The fiduciary must still exercise care, skill, and caution in making decisions to acquire or retain the investment." RESTATEMENT (THIRD) OF TRUSTS $\S 91$, cmt. f (2007).

${ }^{39}$ On the basis of SEC filings of institutional stock holdings prior to 1990, Del Guercio concluded that bank trust departments were the most conservative institutional investors. Diane Del Guercio, The Distorting Effect of the Prudent Man Laws on Institutional Equity Investments, 40 J. FIN. ECON. 31 (1996). Although Del Guercio did not exploit differences in state laws and lumped ERISA funds and personal trust funds together (few states adopted the new prudent investor rule during the period of her study), she attributed bank trust departments' relative conservatism to the prudent man rule.

Using SEC filings from 1983 to 1997, Bennett, Sias, and Starks examined differences in asset allocations across institutional investors, likewise finding that bank trust departments invested quite conservatively. James A. Bennett, Richard W. Sias \& Laura T. Starks, Greener Pastures and the Impact of Dynamic Institutional Preferences, 16 REv. Fin. STUd. 1203 (2003).

Taking a different approach, but reaching a similar result, Longstreth surveyed the 50 largest bank trust departments, college and university endowments, private foundations, and corporate pension fund sponsors. Of the institutions that replied, bank trust departments reported being most constrained by the legal standards governing their investment practices. Bevis Longstreth, Modern InVESTMENT Management AND the PRUdent MAn Rule (1986).

${ }^{40}$ See, e.g., Jeffrey N. Gordon, The Puzzling Persistence of the Constrained Prudent Man Rule, 62 N.Y.U. L. Rev. 52 (1987); Langbein and Posner, supra note 27; Longstreth supra note 39. For an accessible introduction to modern portfolio theory, see Jonathan R. Macey, An Introduction to Modern Financial THEORY (2d ed. 1998). 
isolation because risk is correlated with return. "This calculation is called the risk/return curve: The higher expected return on the investment compensates me for bearing the greater risk of the investment being disappointing." ${ }^{41}$ Stock has a greater default risk than corporate bonds, and corporate bonds have a greater default risk than U.S. government bonds. But their expected returns reflect these differences in default risk. ${ }^{42}$ The focus should not be on risk in the abstract, but rather on the tradeoff of risk and return that best suits the trust in view of its purpose and the risk tolerance of the beneficiaries.

The critics pointed to the further insight from portfolio theory that the prudence of an individual investment cannot be assessed without attention to the portfolio as a whole. Suppose investment $A$ is high risk and investment $B$ is low risk. Even if neither is suitable for the trust in isolation, a simultaneous investment in both might provide just the right mix of risk and reward. An investment in a company that makes suntan lotion looks very different if paired with an investment in a company that makes rain umbrellas versus a company that makes beach umbrellas. What is now understood is that unsystematic risk, which is to say firm- and industryspecific risk, tends to be inversely correlated across firms and industries. Unlike systematic or market risk, unsystematic risk can therefore be removed through diversification.

The critics also noted that investment in long-term, fixed-rate obligations with little default risk such as government bonds, which were favored under the old prudent man rule, exposed the trust to infla- tion risk. When the rate of inflation exceeds the interest rate on the bond, in real value the trust estate shrinks.

In response to the cogency of these criticisms, in the mid to late 1980s a handful of states repealed the prudent man rule in favor of a new prudent investor rule. But widespread repeal of the prudent man rule did not come until the 1990s, when the rule received two decisive deathblows. First, in 1992, the American Law Institute published an interim revision to the trust investment sections of the Restatement of Trusts. ${ }^{43} \mathrm{Sec}$ ond, in 1994, the Uniform Law Commission promulgated the Uniform Prudent Investor Act. The core reforms of the new Restatement and Uniform Act, which implement the teachings of modern portfolio theory, have been adopted in all states, primarily though not exclusively through enactment of the UPIA. ${ }^{44}$

Figure 1, below, shows the percentage of trust assets in our sample data held in stock and the percent-

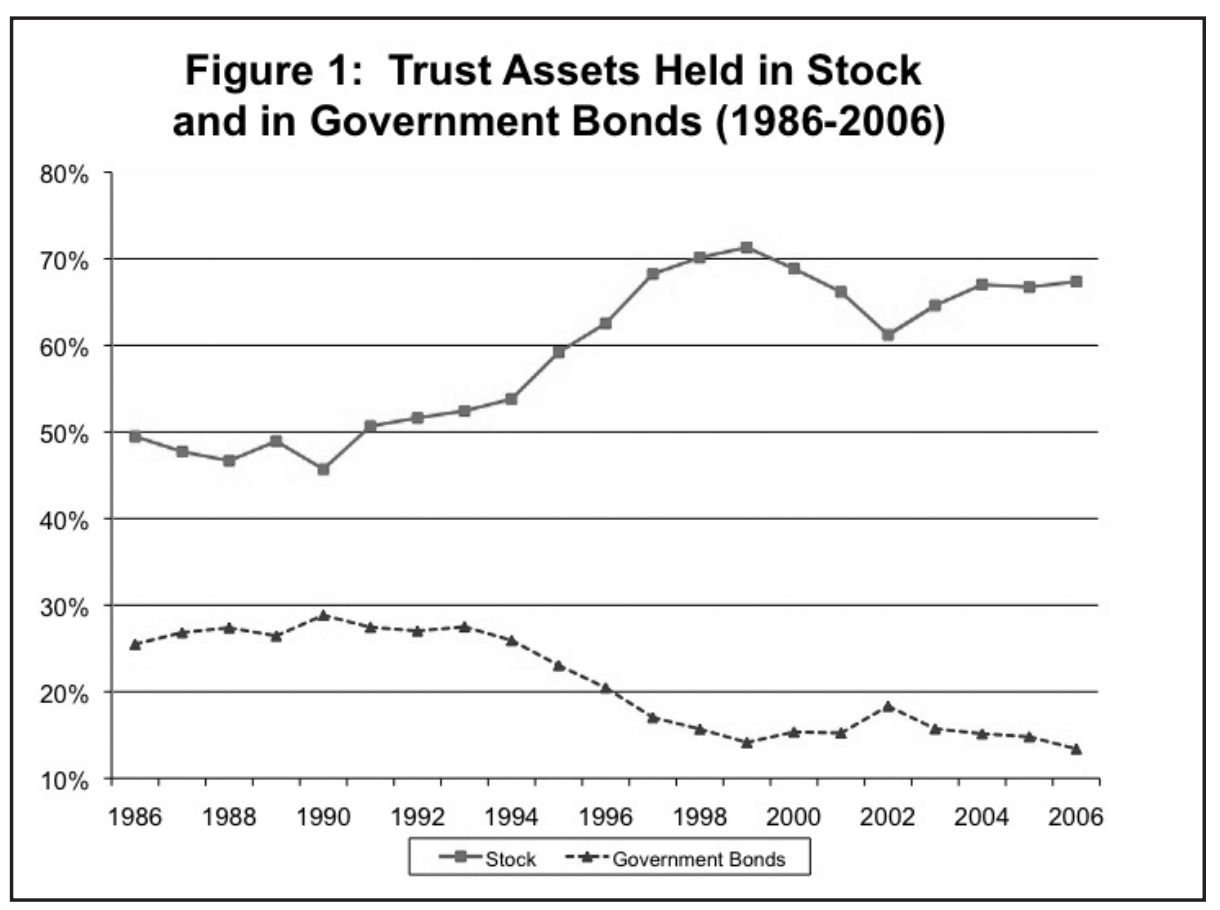

${ }^{41}$ John H. Langbein, The Uniform Prudent Investor Act and the Future of Trust Investing, 81 IowA L. REV. 641, 647 (1996).

${ }_{42}$ Between 1926 and 2008, the average annual return on large company stocks was 11.7 percent; on long-term corporate bonds was 6.2 percent; on long-term government bonds was 6.1 percent; and on treasury bills was 3.8 percent. 2009 Iввотson STOCKS, Bonds, Bills, and Inflation Classic Yearbook, at Table 2-1. See also J. Bradford DeLong \& Konstantin Magin, The U.S. Equity Return Premium: Past, Present, and Future, 23 J. Econ. Persp. 193 (2009).

${ }^{43}$ See Restatement (Third) of Trusts: Prudent InVestor RULE (1992). This interim 1992 volume was superseded and renumbered in 2007 by the third volume of the finalized Restatement
(Third) of Trusts. See Restatement (ThiRd) OF Trusts at p. 287 (2007) (Introductory Note to Chapter 17).

${ }^{44}$ We treat any statute that instructs courts to evaluate the prudence of a particular investment in light of the composition of the trust portfolio as a whole as an adoption of the prudent investor rule even if the statute is not based on the Restatement (Third) of Trusts or the UPIA. The Appendix details our dating of the modern prudent investor laws. The UPIA is more complete than some of the earlier statutes in that it expressly abolishes all categorical restrictions on investments, UPIA $\S 2$ (e), and forbids hindsight review, UPIA $\S 8$. The Restatement and UPIA also fold the duty to diversify into the duty of prudence. See UPIA $\S 3$; RESTATEMENT (THIRD) OF TRUSTS $§ 90(b)$ (2007). 
age held in government bonds for the period 1986 through 2006. ${ }^{45}$ There are unmistakable, mirror-image trends with stock holdings increasing and government bond holdings decreasing in the years following the promulgation of the Restatement (Third) of Trusts in 1992 and the Uniform Prudent Investor Act in 1994.

\subsection{Does Default Trust Investment Law Matter?}

As reformulated (and made gender neutral), the new prudent investor rule provides that the "trustee's investment and management decisions respecting individual assets must be evaluated not in isolation but in the context of the trust portfolio as a whole and as a part of an overall investment strategy having risk and return objectives reasonably suited to the trust." ${ }^{46}$ Like the old law, the new law is nominally a default rule that may be altered by the terms of the trust. ${ }^{47}$

Default rules should matter only in the presence of transaction costs. If the settlor can easily specify investment directions in the trust instrument, and if the trustee's compliance with those instructions is easily observed, the change in prudent trust investment standards should have had little effect on trust investment in practice. Taking notice of survey evidence that optouts from the prudent man rule were common, ${ }^{48}$ scholars such as Jeffrey Gordon, John Langbein, and Richard Posner theorized that the old rule endured for so long in part because sophisticated parties opted out of its application. ${ }^{49}$
There are, however, good reasons to suppose that the default rules of prudent trust investment law nonetheless influence trust investment in practice. The conditions of financial markets, the needs of the beneficiaries, and the identity of the beneficiaries may vary over time. It is not feasible for the settlor to specify in advance how the trustee should invest in all contingent future states of the world. "The modern trustee conducts a program of investing and managing financial assets that requires extensive discretion to respond to changing market forces." ${ }^{50}$ This is to say that trust agreements are incomplete contracts for which default fiduciary rules necessarily remain relevant. ${ }^{51}$

Under the old law, moreover, the trustee's litigation risk was asymmetric. Typically the beneficiary would not have a viable cause of action for a too-conservative portfolio (government bonds were effectively per se prudent). ${ }^{52}$ But if an investment in stock did not pay off, in hindsight courts sometimes deemed it to have been imprudent speculation even if the investment was sensible ex ante in light of the portfolio as a whole. ${ }^{53}$ Typical industry compensation arrangements, which are based on the total corpus of the trust and are usually 1 percent or less per annum, ${ }^{54}$ exacerbated this problem by providing little incentive for the trustee to make more aggressive investments given the asymmetric litigation risk..$^{55}$

In general, the new law applies prospectively to existing trusts. ${ }^{56}$ Thus, after adoption the new prudent investor rule applies to the trustee's subsequent invest-
3.1 .

${ }^{45}$ The nature and sources of our data are detailed in Section

${ }^{46}$ UPIA $\S 2$ (b). Restatement (Third) of Trusts § 90(a) (2007) is to similar effect. For discussion, see Edward C. Halbach, Jr., Trust Investment Law in the Third Restatement, 77 IowA L. REV. 1151 (1992); Langbein, supra note 41.

${ }^{47}$ UPIA $\S 1$ 1(b); RESTATEMENT (THIRD) OF TRUSTS $§ 91(b)$ (2007).

${ }^{48}$ See Gordon, supra note 40, at 76 n.99.

${ }^{49}$ Richard A. Posner, Economic Analysis of LaW 478-479 (7th ed. 2007); Gordon, supra note 40, at 75-76; Langbein \& Posner, supra note 27 . Gordon also examined the political economy of trust law reform and other institutional features of trust practice as complementary explanations for the durability of the prior law. Although Langbein and Posner emphasized the default nature of the prior law, in more recent work Langbein predicted an increase in trust investment in equity following adoption of the new prudent investor rule. Langbein, supra note 41, at 654 n.83.

${ }^{50}$ Langbein, supra note 4, at 54.

${ }^{51}$ Recall also that judicial enforcement of opt-outs is uncertain. See supra note 38 and accompanying text.

${ }_{52}$ As Langbein has put it, "under traditional law beneficiaries have had little recourse when trustee performance has been indifferent, but not so egregious as to be in breach of trust." John H. Langbein, The Uniform Trust Code: Codification of the Law of
Trusts in the United States, 15 TR. L. INT'L 66, 76 (2001).

${ }_{53}$ See supra note 37 and accompanying text. Adding to the asymmetric litigation risk is the rule that professional trustees, such as the institutional trustees in our sample, are held to an even higher standard of care. See UPIA § 2(f); RESTATEMENT (THIRD) OF TRUSTS § 77(3) (2007).

${ }^{54}$ For an example, see Dukeminier, SitKoff \& Lindgren, supra note 1 , at 551 n.4.

${ }^{55}$ Often the purpose of the trust is to supply steady income to the surviving spouse and children, who have a low tolerance for risk. By contrast, an institutional trustee with a portfolio of trust funds under management is likely to be risk neutral, or at least less risk averse than the individual beneficiaries. For this reason, the benefits of trying to solve the incentive problem by setting the trustee's compensation in relation to the trust's annual return are likely to be outweighed by the costs of exacerbating the risk-sharing problem. The fundamental difficulty is that the solution in the textbooks on economics to the principal-agent problem with a riskaverse principal and a risk-neutral (or at least less risk-averse) agent, selling the project to the agent, is foreclosed by the transferor's use of the trust form instead of an outright transfer. On this account, the settlor is the trustee's primary principal. See Sitkoff, supra note 23, at 648-649.

${ }^{56}$ See UPIA $\S 11$. 
ment decisions, including the failure within a "reasonable time" to reallocate a portfolio that was in compliance with the old law but does not satisfy the new law. ${ }^{57}$ However, compliance with the new law will not always require a portfolio reallocation. The risk tolerance of the beneficiaries and the purpose of the trust may require a conservative investment strategy-for example, the paradigmatic trust for the benefit of a widow and orphans. ${ }^{58}$ Further, the new law does not require immediate reallocation if the benefits of doing so are outweighed by the attendant tax and other transaction costs.

Accordingly, the extent to which adoption of the new prudent investor rule caused a change in trust portfolio allocation will be a function of the risk tolerance of the beneficiaries of the trusts in our sample, the transaction costs of portfolio reallocation and the meaning of "reasonable time," and the extent to which settlors had been able successfully to opt out of the prior law.

\section{Research Design}

\subsection{The Data}

\subsubsection{Trusts in the Federal Reserve System}

The trust data examined in this study come from annual reports to federal banking authorities by financial institutions such as banks, savings and loan associations, and trust companies that are part of the Federal Reserve System. Federal law requires these institutions to report their trust holdings, including total trust assets, number of trust accounts, and alloca- tion of trust assets across certain investment categories. The data are at the institution level; individual account data are not reported. ${ }^{59}$

The trust holdings of reporting institutions are categorized as Employee Benefit Trusts, ${ }^{60}$ Personal Trusts, and Estates. The Personal Trusts category, on which we focus, includes private and charitable trusts, both inter vivos and testamentary, but excludes commercial trusts and employee benefit plans. Reporting institutions state their holdings as of December 31 of the reporting year. We therefore code adoptions of the prudent investor rule as taking place in the year the legislation took effect. ${ }^{61}$

\subsubsection{Trust Asset Allocation}

The asset allocation of reported trust holdings is broken down into the following categories: (1) stock (common and preferred combined) ${ }^{62}(2)$ interest-bearing accounts, (3) U.S. treasuries, (4) local government bonds, (5) money market funds, (6) other short-term obligations (mainly commercial paper), (7) other bonds, (8) mortgages, (9) real estate, and (10) miscellaneous. "Other bonds" includes corporate and foreign government obligations, and "real estate" includes a variety of real estate investments. As discussed below, we use the percentage of stock holdings as our primary outcome variable. We also examine the percentage of "safe" holdings, with "safe" defined consistent with the old prudent man rule to include federal, state, and municipal bonds, interest-bearing bank accounts, money market funds, and mortgages. ${ }^{63}$

Because the data do not detail individual holdings within asset classes, we cannot examine the effect
57 See UPIA § 4; RESTATEMENT (THIRD) OF TRUSTS § 92 (2007).

${ }^{58}$ As the official comment to UPIA $\S 2$ explains, "tolerance for risk varies greatly with ... the purposes of the trust and the relevant circumstances of the beneficiaries. A trust whose main purpose is to support an elderly widow of modest means will have a lower risk tolerance than a trust to accumulate for a young scion of great wealth." In a similar vein, the contemporaneous practitioner literature predicted that adoption of the new rule "will not cause a radical restructuring of existing trust investment portfolios," but rather would affect only "those trusts having purposes and circumstances which would cause the prudent investor to invest a portion of the portfolio in more growth-oriented, less conservative types of investments, or to apply more aggressive and sophisticated management techniques." Lyman W. Welch, How the Prudent Investor Rule May Affect Trustees, TR. \& EsT., Dec. 1991, at 15, 20-21.

${ }^{59}$ From 1968 until 2001, the Federal Financial Institutions Research Council published annual reports of trust holdings by regulated entities, summarizing the results by state. Since 2001, the Federal Deposit Insurance Corporation (FDIC) has published those reports and has made the institution-level data available online. An interactive web site allows one to obtain the data by state. Federal
Deposit Insurance Corporation, Statistics on Depository Institutions, http://www2.fdic.gov/sdi/main.asp. Older reports, from 1996 through 2000, are also available. Federal Deposit Insurance Corporation, Trust Institutions Information, http://www2.fdic.gov/structur/trust/index.asp. The FDIC provided us with a CD-ROM of institution-level data from 1986 through 2000.

${ }^{60}$ Employee Benefit Trusts is divided into two categories: (1) when the institution exercises investment discretion as trustee, and (2) when the bank is an investment manager as defined in section 3(38) of ERISA, 29 U.S.C. § 1002(38). We use only data reported in the first category, when the institution acts as trustee. When the reporting institution operates as an investment manager instead of a trustee, its investment decisions are subject to direction from the trustee, and the institution may be responsible for only a subset of the fund's assets. For example, a trustee might allocate a portion of the trust fund to bank $A$, directing $A$ to invest its share of the fund entirely in stock, while allocating the rest of the fund to bank $B$, directing $B$ to invest entirely in mortgages and bonds. See, e.g., In re Unisys Savings Plan Litigation, 74 F.3d 420, 439 (3d Cir. 1996).

${ }^{61}$ See Appendix. 
of the new prudent investor rule on shifts within an investment class. For example, we cannot observe shifts from stock in large companies to stock in small companies, or from stock in dividend-paying companies to stock in non-dividend-paying companies. Nor can we examine the effect of the new rule on asset allocation within individual trusts, as the data are at the state and institution levels.

What the data do show is the percentage of aggregate holdings that are held in each of the ten specified asset classes, including stocks, corporate bonds, government bonds, and real estate. ${ }^{64}$ Although more granular data would be preferable, these coarser data nevertheless allow for examination of changes in the relative proportion of trust assets held in the different asset classes before and after adoption of the prudent investor rule. To that end, we take the percentage of trust assets held in stock as our primary outcome variable. We examine the changes in the percentage of personal trust assets held in stock in the states that adopted the new rule relative to the changes in such holdings in states that did not adopt the new rule.

Percentage of trust assets held in stock is an illuminating outcome variable because the old prudent man rule disfavored broad classes of equity holdings. If the prior law constrained trust asset allocation, we would expect to see reallocation toward equity after adoption of the new rule. Further, increased stock holdings at the expense of government bonds and other investments with little to no default risk would imply higher-risk portfolios. Thus, an observable increase in the percentage of stock holdings is a suitable proxy for movement outward on the risk and return curve. ${ }^{65}$

\subsubsection{Charitable and Revocable Trusts}

The inclusion of charitable trusts and revocable trusts in the Personal Trusts category has the potential to dampen our results, working against a finding that the new prudent investor rule affected trust asset allocation. ${ }^{66}$ Charitable trusts are indeed subject to the prudent investor rule. ${ }^{67}$ But they lack an ascertainable beneficiary with an economic incentive to enforce the trust. Instead, charitable trusts are enforced by the state attorney general, and in practice such enforcement is rare. ${ }^{68}$ The absence of significant fiduciary enforcement activity for charitable trusts could attenuate the effect of changes in the applicable fiduciary rules.

With respect to revocable trusts, the modern law provides that the trustee owes fiduciary duties only to the settlor, not to the beneficiaries. ${ }^{69}$ The theory is that because the settlor retains the power to revoke the trust, it is a will substitute, and the trust property should be regarded as belonging to the settlor. ${ }^{70}$ Under the modern law, therefore, the trustee is subject to the settlor's direction in managing the trust

\footnotetext{
${ }^{62}$ Shares in certain mutual funds (but not municipal bond funds, which are reported as local government bonds, or money market funds, which have their own category) are reported as stock holdings. To the extent that shares in mutual funds are reported as stock even if the underlying mutual fund is invested in bonds, the relative percentage of stock holdings might be overstated. This potential overstatement does not undermine our research design, however, for several reasons.

First, most of the year-to-year variation in the variable for percentage of stock holdings can be explained by stock market movements. This indicates that the trust holdings reported as stock are correlated with the stock market.

Second, in the period under study, mutual funds moved aggressively into corporate bonds, foreign government bonds, and high-yield bonds, holding more in those categories than U.S. government bonds by the mid-1990s. See Investment Company Institute, 2009 Investment Company FaCt Book: A Review of TRENDS AND ACTIVITY IN THE INVESTMENT COMPANY INDUSTRY at Table 29 (2009). As compared with U.S. government bonds, these other types of bonds are associated with a greater risk of default and exchange rate risk. Hence, any increase in percentage of stock holdings that is attributable to mutual fund holdings would still imply a riskier portfolio, which is our underlying inquiry.

Third, in unreported regressions we combined the separately-reported corporate bonds category with stock holdings and found slightly stronger effects, which implies that we have not con-
}

flated a movement from corporate bonds to corporate bond mutual funds with an increase in stock holdings (regressions on "other bonds" alone showed a weak positive effect of the reform). See infra note 86.

${ }^{63}$ The remaining investment categories, "other bonds," "real estate," and "short-term obligations," varied substantially over the period and resist classification, and in any event typically amounted to less than 10 percent of the average state's aggregate portfolio.

${ }^{64}$ See text accompanying supra notes 62-63.

${ }^{65}$ See Section 4.2.2.

${ }^{66}$ Noise in the data that might drive a spurious correlation is a problem for empirical research design. That problem is not present here, because inclusion of charitable and revocable trusts introduces noise that works against rather than in favor of a statistically significant result.

${ }^{67}$ See 5 Austin WaKeman Scott, William Franklin Fratcher \& Mark L. Ascher, ScotT AND Ascher on Trusts $\S 37.3 .8$ (4th ed. 2008).

${ }^{68}$ See Jonathan Klick \& Robert H. Sitkoff, Agency Costs, Charitable Trusts, and Corporate Control: Evidence from Hershey's Kiss-Off, 108 Colum. L. REv. 749, 779-782 (2008).

${ }_{69}$ Uniform TRust Code $§$ 603(a) (2000, rev. 2004); RestateMENT (THIRD) OF TRUSTS $§ 74$ (2007).

70 See Restatement (THIRD) OF TRusts $\S 74$, cmt. a (2007); see also Langbein, supra note 5, at 1126-1129. 
portfolio. ${ }^{71}$ Until the trust becomes irrevocable, the trustee is not liable to the beneficiaries for imprudent portfolio management. Accordingly, changes in trust fiduciary law should not have a significant effect on the administration of revocable trusts.

\subsubsection{Timeframe}

Although the data are available from 1986 through the present, we examine only the years 1986 through 1997 for three reasons. First, the data are reported by state of the reporting institution's charter. Prior to 1997, interstate banks tended to operate as bank holding companies, which the Federal Reserve designates as the "high holder," with separately chartered and therefore separately reporting banks in different states. ${ }^{72}$ Although there is flexibility in the choice-of-law rules, the applicable fiduciary law is typically the law of the trustee's state of residence. Accordingly, our coding of the prudent investor rule enactments should capture the law applicable to the reported assets.

Beginning in 1996, however, banks and bank holding companies were authorized to convert independently chartered banks in other states into branch offices of a single interstate bank, ${ }^{73}$ and a large wave of consolidations took place in the late 1990s. Because the data are collected by institution and then aggregated by the chartering state of the reporting institution, the interstate bank mergers and branching of the late 1990s has the potential to bias our results by changing the state in which assets are reported without a corresponding change in governing law.

Second, many states reformed their rules governing the accounting of principal and income after 1997. These reforms, chiefly unitrust and equitable adjustment legislation, could affect trust asset allocation because they made less rigid the formal distinction between capital gains and income. ${ }^{74}$ Prior to 1997 , principal and income rules were for the most part uniform across the states.

Third, state laws concerning the rule against perpetuities and self-settled asset protection trusts became significantly differentiated beginning in $1997 .{ }^{75}$ Although these changes do not bear directly on trust investment law, they nonetheless have the potential to affect trust investment practice. Perpetual trusts and self-settled asset protection trusts have a different time horizon and purpose that might warrant heavier investment in equities. ${ }^{76}$

\subsection{The Natural Experiment}

Figure 2 depicts the adoption pattern of the prudent investor rule statutes between 1986 and 1997, the period under study. The substantial temporal and geographic variation means that there were repeated "natural experiments" on the effect of the new rule on trust asset allocation. 2005).

${ }^{71}$ See McGinley v. Bank of America, 109 P.3d 1146 (Kan.

72 Banks could maintain interstate branches under narrow circumstances prior to 1997 , but a study conducted by the Federal Reserve found that few banks did so. See Susan McLaughlin, The Impact of Interstate Banking and Branching Reform: Evidence from the States, 1(2) CURRENT Issues In ECON. \& Fin. 1 (1995).

${ }^{73}$ Riegle-Neal Act of 1994, Pub. L. No. 103-328, 1994 U.S.C.C.A.N. 2338.

${ }^{74}$ Prior to the principal and income reforms, the form of the investment return determined its classification as income or principal. The problem with this approach is that trusts are commonly set up to pay income to one beneficiary for life (often a surviving spouse) and then the principal to another beneficiary (such as a surviving child) on the life beneficiary's death. For example, suppose $T$ bequeaths a fund to $X$ in trust to pay the income to $A$ for life and then the principal to $B$ on $A$ 's death. If $X$ invests in bonds or in stocks that pay a cash dividend, under traditional law $A$ is benefited because interest on bonds and cash dividends on stock are classified as income. By contrast, if $X$ invests in stocks that do not pay a cash dividend, under traditional law $B$ is benefited because stock appreciation is classified as principal. Because the trustee has a duty to act impartially, giving due regard to the needs of the income and principal beneficiaries, the principal and income rules bear directly on the trustee's asset allocation. See Restatement (THIRD) OF TRUSTs (T.D. No. 5, 2009) (Introductory Note to Chapter 23); Christopher P. Cline, The Uniform Prudent Investor and Principal and Income Acts: Changing the Trust Landscape, 42 REAL. ProP. PRoB. \& TR. J. 611 (2008).

${ }^{75}$ See Sitkoff \& Schanzenbach, supra note 11. With the single exception of Delaware's abolition of the rule against perpetuities in 1995, all of these changes occurred in 1997 or later. See id. at 430433, table 1.

${ }^{76} I d$. at $385-387$. Regressions on the full sample tended to decrease the coefficient estimates a bit, but the results remained statistically significant. 


\section{Figure 2: Prudent Investor Rule Adoptions (1997)}

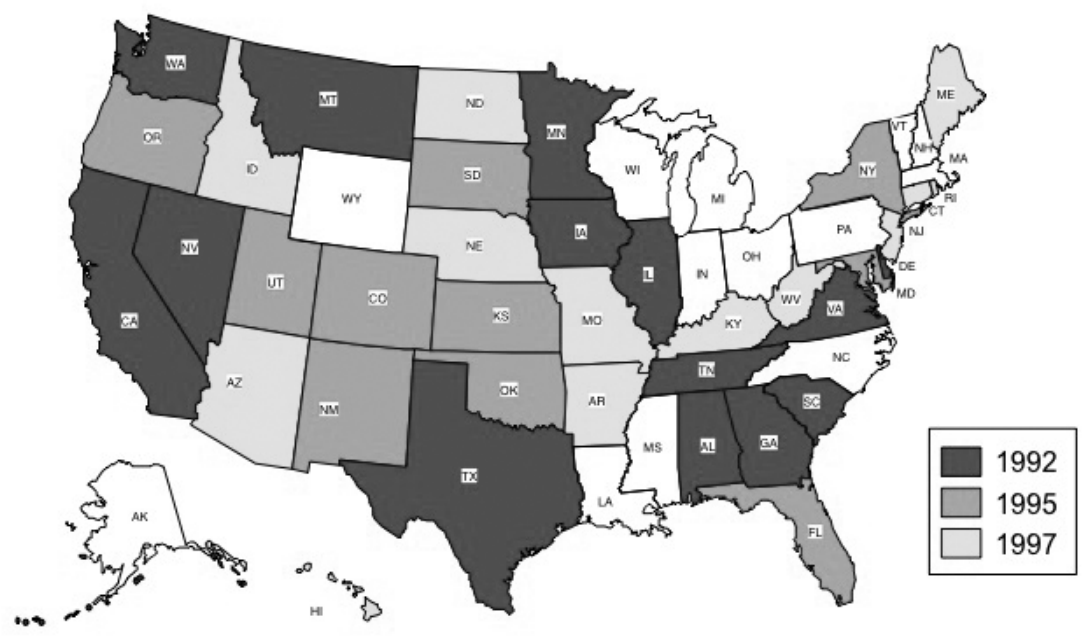

changes in the percentage of trust assets held in stock in nonadopting states in the same years (thus "differences-in-differences").

The theory is that factors other than the new rule, such as general economic conditions, affect both groups similarly and thus are accounted for by focusing on the differences between the two groups. At the same time, factors idiosyncratic to a particular state are accounted for by examining the differences in the state's asset allocation before and after the reform. In addition, the variation over time allows us to separate the effect of the rule from other contem-

The key to our research design is the repeating nature of the natural experiment. Different states adopted the prudent investor rule at different times. We examine trust asset allocation in each adopting state after the rule's adoption in relation to the state's trust asset allocation prior to adoption, and we use the contemporaneous trust asset allocation in the other states as a control. This empirical strategy, called "differences-in-differences" regression, ${ }^{77}$ is a well-accepted and widely-used statistical technique for assessing the effect of a change in some but not all of a group. In our context, the group is the states, and the change is the adoption of the prudent investor rule. Roughly speaking, we examine the changes in the percentage of trust assets held in stock before and after adoption of the new rule in adopting states, and subtract the poraneous trends, such as stock price fluctuations or evolving investor preferences. ${ }^{78}$

As further checks, we include controls to account for other sources of variation across the states that might affect trust asset allocation. For example, we include controls for state income, population, and total trust assets under management (the last on the theory that it might proxy for sophistication of the trustee and risk tolerance of the beneficiaries). We also use "year fixed effects," which accounts for common time factors such as yearly stock market returns. ${ }^{79}$

To account for changing risk preferences and evolving investment culture, we use the percent of stock in ERISA funds as yet another control. Portfolio management in ERISA funds is subject to a duty of prudence under ERISA, not state trust law, and ERISA
${ }^{77}$ For a formal presentation of our empirical strategies, including our various regression models, see Schanzenbach \& Sitkoff, supra note 12, at 692-695.

${ }^{78}$ The interim volume of Restatement (Third) of Trusts on the prudent investor rule, published in 1992 as approved by the American Law Institute in 1990, is perhaps the most important contemporaneous factor bearing on trust asset allocation. However, unlike the state prudent investor rule statutes, the Restatement is not statespecific. Accordingly, our strategy of exploiting variation over time in the state enactments should control for any effect of the Restatement, isolating the separate effect, if any, of the prudent investor rule statutes. Moreover, as a further check we ran regressions estimating the effect of the prudent investor rule statutes before and after the Restatement. In some of these regressions we found no additional effect of the Restatement; in others, we found that after the Restatement, stock holdings increased in reform states even more relative to nonreform states. Consequently, although we can draw no firm inferences about any independent effect of the Restatement, we can conclude that the state prudent investor rule statutes had an effect on trust asset allocation independent of the Restatement.

On balance, we think that the Restatement had little independent effect in states that did not adopt a prudent investor rule statute. As discussed below in Section 4.2.2, most of the increase in percentage stock holdings is traceable to the prudent investor rule statutes and general stock market appreciation. There is no otherwise discernable trend beginning at the Restatement's promulgation. However, because we lack the sort of variation that would allow for clean identification of the Restatement's impact, we draw no firm conclusion.

${ }^{79}$ See Section 4.2.4. 
has been interpreted in accord with the new prudent investor rule since at least $1979 .{ }^{80}$ Consequently, asset allocation under ERISA should be less sensitive to changes in state prudent investor rules than personal trusts but similarly sensitive to general market trends and institutional tastes for equity.

As a final robustness check, we use ERISA funds as a control group. In these regression models, we took as our outcome variable the difference between (a) the year-to-year change in the percentage of trust assets held in stock in reform states relative to nonreform states, and (b) the year-to-year change in the percentage of ERISA fund assets held in stock in reform states relative to nonreform states. In effect, these regressions add a further layer of differencing. Factors bearing on institutional preferences for equity common to personal trusts and ERISA funds are therefore removed, further isolating the effect of the state prudent investor rule. ${ }^{81}$

\section{Results}

\subsection{Graphical Analysis}

Figure 1, presented above in Section 2.3 , shows a clear national trend toward increased trust holdings in stock and decreased holdings in government bonds in the years following the promulgation of the Restatement (Third) of Trusts (1992) and the Uniform Prudent Investor Act (1994).

Figure 3 shows the same trend but at the state level. Each dot on the graph represents an individual state's percentage of trust holdings in stock or government bonds in the indicated year. Each year therefore has 100 dots, 50 for percentage of stock holdings and 50 for percentage of government bond holdings. The same trend toward increased trust holdings in stock and decreased holdings in government bonds is evident. However, there are substantial differences in the timing and magnitude of the trend across the states, as indicated by the vertical spread of the dots in each year. We hypothesize that the asynchronous timing of the states' adoption of the prudent investor rule explains some of this variance.

To test this hypothesis, Figure 4 depicts the percentage of trust holdings in stock and in "safe" investments in states that adopted the prudent investor rule in the years before and after the rule's adoption. We define "safe" in line with the old prudent man rule to mean government bonds, interest-bearing bank accounts, money market funds, and mortgages. We took the year of adoption of the rule as year zero, and detrended the data to remove year-to-year market fluctuation. ${ }^{82}$
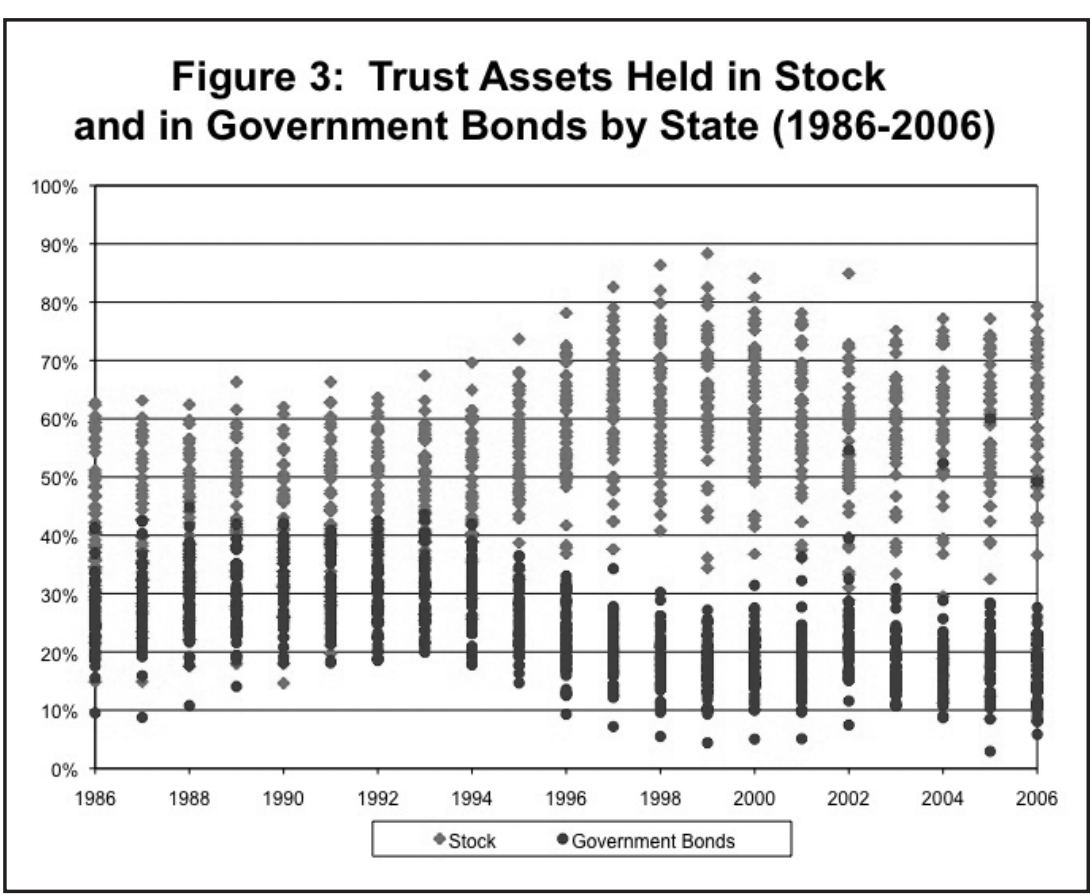

${ }^{80}$ Under an authoritative 1979 regulation, prudence under ERISA requires consideration of the role that each investment plays in the context of the portfolio as a whole. See 29 C.F.R. $\S 2550.404 a-1(b)(1)(i)$ (interpreting ERISA $\S 404(a)(1)(B), 29$ U.S.C. $\S 1104(\mathrm{a})(1)(B))$. The official commentary to the regulation explains: "The 'prudence' rule in the Act sets forth a standard built upon, but that should and does depart from, traditional trust law in certain respects. The Department is of the opinion that (1) generally, the relative riskiness of a specific investment or investment course of action does not render such investment or investment course of action either per se prudent or per se imprudent, and (2) the prudence of an investment decision should not be judged without regard to the role that the proposed investment or investment course of action plays within the overall plan portfolio." 44 Fed. Reg. 37,221, 37,222 (June 26, 1979). The federal courts therefore employ a total-portfolio approach in ERISA litigation involving the prudence of individual pension trust investments. See Laborers National Pension Fund v. Northern Trust Quantitative Advisors, 173 F.3d 313, 322 (5th Cir. 1999) (reversing because the court below reviewed the investment in question "in isolation under the common law trust standard, instead of according to the modern portfolio theory required by ERISA policy as expressed by the Secretary's regulations").

${ }^{81}$ Although we do not report the results in this article, in our underlying study we also examined the data at the institution level, with results that are comparable to our state-level findings. See Schanzenbach \& Sitkoff, supra note 12, at Tables 2 and 4.

${ }^{82}$ We detrended by running a regression with only year dummies on the full sample (1986 through 1997), with 1986 as the excluded year, and then subtracted the year coefficients from the observed average in that year. 


\section{Figure 4: Percentage Stock and Percentage "Safe" Before and After Reform (Detrended)}

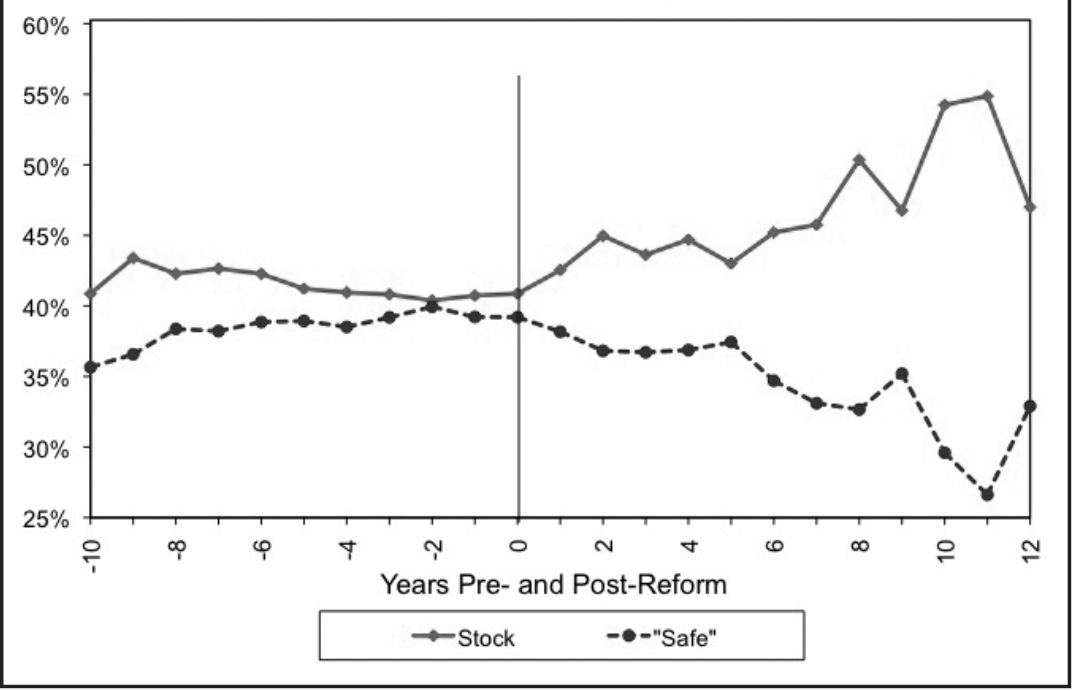

adopted the new rule held more stock-on the order of 1 to 4 percent, depending on the year-at the expense of "safe" investments. ${ }^{83}$

The foregoing graphical analysis provides strong support for the hypothesis that enactment of the new prudent investor rule led to a reallocation to holdings in stock. Such a reallocation suggests movement outward on the risk and return curve. In the next section we report the results of more rigorous tests statistical inference. As we shall see, those results are consistent with the graphical analysis.

\subsection{Regression Analysis ${ }^{84}$}

We undertook a series of differencesin-differences regressions using a basic model and a host of alternate specifications as robustness checks. These regressions

The lines for stock and "safe" investments are almost perfect mirror images, with what appears to be a shift from "safe" investments to stock after adoption of the new prudent investor rule. Prior to the new rule, both lines are basically flat, and the reform has an almost immediate effect that increases over time. Thus, Figure 4 strongly suggests that the reallocation trend did not predate the reform and that the reform was not enacted in response to changing trust investment practices. Put otherwise, Figure 4 provides powerful evidence that the reform caused the reallocation from government bonds to stock and was not merely associated with it.

Figures 5 and 6, below, point in the same direction but from another perspective. These Figures trace the percentage of stock and the percentage of "safe" investments in personal trusts by reform status of the state. Again we observe a persistent difference between reform and nonreform states, with the average trust in the reform states holding more stock and fewer "safe" investments. Taken together, these Figures suggest that trusts in states that showed a consistent, statistically significant reallocation in trust holdings from "safe" investments to stock after a state's adoption of the new prudent investor rule.

\subsubsection{Percentage Stock in Personal Trusts}

In the most basic model, we found that the average trust's stock holdings increased by 1.72 percentage points after enactment of the new rule. When we add as controls each state's total state trust assets and percentage of ERISA funds held in stock, the result increases slightly to 2.11 and is even more statistically significant. To put these results in perspective, in the period under study the average state held 47 percent of its personal trust assets in stock, and the average state's stock holdings increased roughly 14 percentage points. Taking the 2.11 point finding at face value, our results imply that adoption of the new prudent investor rule explains about 15 percent of the increase in stock holdings in the period under study. ${ }^{85}$
${ }^{83}$ The gap between the reform and non-reform lines changes as states switch from one category to the other. For example, in 1997, the non-reform states had higher stock holdings than reform states. However, nine states adopted the UPIA in 1997, and those states had lower stock holdings at the time of adoption. Likewise, we hesitate to draw a strong inference from the higher stock holdings in reform states observed at the beginning of the graph because trustees in the early-adopting states may have been investing more aggressively. The differences-in-differences regression methodology averages out these state-specific factors.

${ }^{84}$ Readers interested in a full recounting of our regression analysis should consult Schanzenbach \& Sitkoff, supra note 12, at 692-707.

${ }^{85}$ A potential concern in differences-in-differences studies is the presence of serial correlation, particularly with financial variables, especially if investment patterns are persistent. See Marianne
Bertrand, Esther Duflo \& Sendhil Mullainathan, How Much Should We Trust Differences-in-Differences Estimates?, 119 Q. J. ECON. 249 (2004). To deal with this problem, we ran regressions controlling for state-specific time trends and others that clustered the standard errors at the state level. The results were similar and remained statistically significant. Another potential difficulty arises from our use of a dependent variable that is a percentage, because the fitted values may lie outside of the 0 to 100 range, hence the liner form of ordinary least squares (OLS) regressions imposes a functional form that must be wrong. Following Leslie E. Papke \& Jeffrey M. Wooldridge, Econometric Methods for Fractional Response Variables with an Application to 401(K) Plan Participation Rates, 11 J. App. Econ. 619 (1996), we ran a specification in which we exponentiated the righthand side. In this specification the result was slightly stronger and remained statistically significant. 


\subsubsection{Percentage "Safe" in Personal Trusts}

To confirm that these increases in stock holdings came at the expense of investments with low default risk favored by the prudent man rule, we reran the same regressions but with "safe" investments, defined as before, as our dependent variable. The results mirrored those of the percentage stock regres-

\section{Figure 5: Percentage Stock by Year and Reform Status}

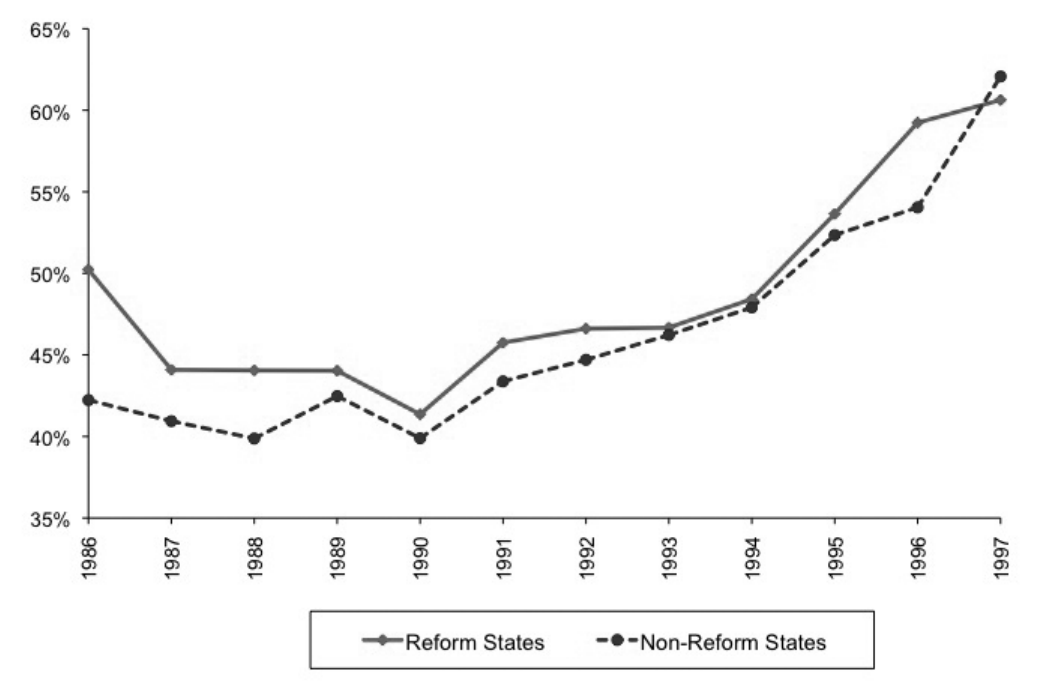

\section{Figure 6: Percentage "Safe" by Year and Reform Status}

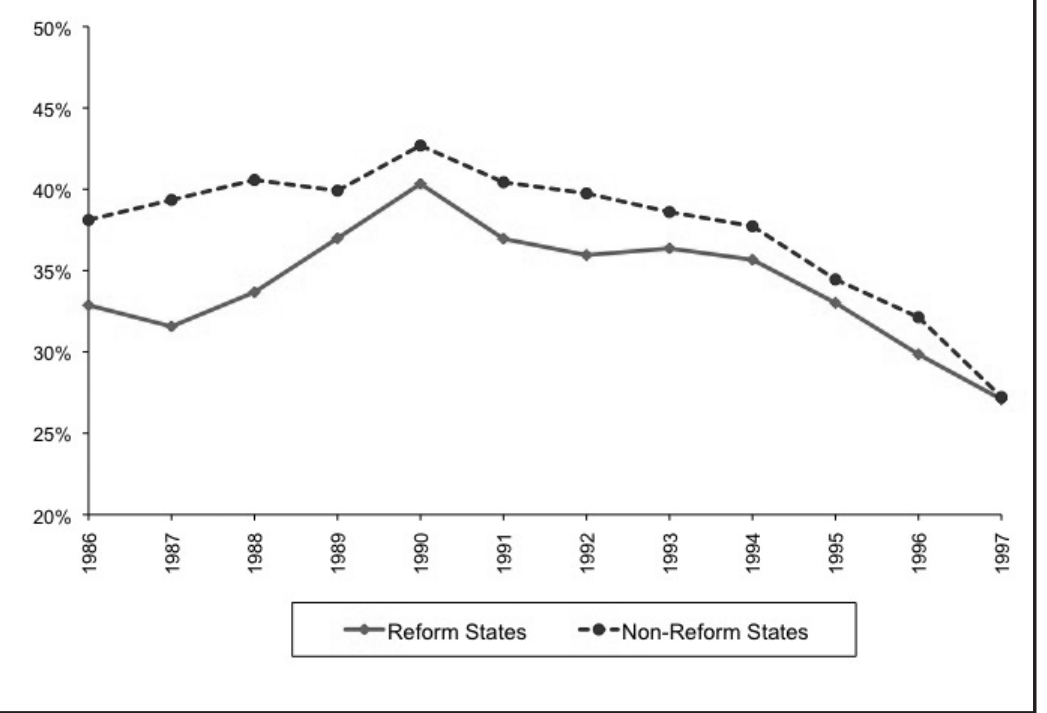

sions, with similar but oppositely signed findings, implying a roughly one-for-one trade-off of "safe" investments for stock. For example, in the basic model with controls for total state trust assets and ERISA funds held in "safe," the result on percentage of "safe" holdings was -2.02 , in comparison to 2.11 for stock holdings in the same model. These results indicate that the observed increase in stock holdings after enactment of the prudent investor rule came at the expense of investments with little to no default risk. We therefore conclude that the new rule prompted movement outward on the risk and return curve. ${ }^{86}$

\subsubsection{Reallocation and "Reasonable Time"}

The foregoing analysis assumes that the effect of the new rule was a single, discrete jump in stock holdings. But there is good reason to suppose that the effect might be gradual, as in Figure 4. New legal rules create uncertainty, and the canonical statements of the new prudent investor rule give the trustee a "reasonable time" to bring the trust portfolio into compliance.$^{87}$ How much time is "reasonable" depends on the tax and other transaction costs of reallocation.

To allow for a more gradual adjustment of portfolios, we examined separately the effect of the rule in the first two years after enactment and in the third and subsequent years after enactment. The long-run (three-plus years) effect of the reform is increased stock holdings of roughly 3 percentage points, a bit more than the 2 percentage points increase estimated above. In addition, to test for the presence of a biasing trend, we examined portfolio allocation in the three years prior to enactment and found no upward trend prior to the new rule. In sum, we found no change in stock holdings in the three years prior to reform, and the effect of the reform appears to have increased over time, consistent with Figure 4.
${ }^{86}$ We derive further confidence in this interpretation of our results from regressions taking the percentage of stock plus the percentage of corporate bonds as our dependent variable. In those regressions we found an even stronger effect of the reform, suggesting reallocation from government bonds to corporate securi- ties. In comparison to government bonds, which have little to no default risk, corporate securities (stocks and bonds) have a greater default risk but a higher expected return.

${ }^{87}$ UPIA § 4; RESTATEMENT (THIRD) OF TRUSTS $§ 92$ (2007). 


\subsubsection{Stock Market Appreciation}

Stock prices appreciated substantially in the period under study. The S\&P 500 nearly tripled between 1990 and 1997, the same period in which Figures 1 and 3 show a clear shift in trust asset allocation from government bonds to stocks. If there is inertia in trust asset allocation, stock price appreciation has the potential to bias our results, particularly if the propensity of a state's institutional trustees to hold stock is correlated with the state's earlier adoption of the prudent investor rule.

We undertook two econometric strategies to ensure that we did not mistake stock market appreciation as reallocation into stock. First, in all regressions we included a control for year-to-year variation, what are known as "year fixed effects." This control variable should remove variation owing to stock market trends independent of changes in the state's statutory prudent investor rules. Second, we ran a series of regressions taking "net percentage stock" as our outcome variable, with net percentage stock defined as the change in percentage of stock holdings in personal trusts minus the percentage change in the S\&P $500 .{ }^{88}$

In the net percentage stock regressions our results were largely unchanged, giving us confidence that our prudent investor rule findings are not artifacts of stock market appreciation. Further, in these regressions the year fixed effects became insignificant, suggesting that the remainder of the increase in stock holdings in the period under study, above that which we have connected to the prudent investor rule statutes, traces to stock market appreciation.

\subsubsection{ERISA Funds Control Group}

As a final robustness check, we undertook a series of regressions taking as our outcome variable the difference between (a) the year-to-year change in the percentage of trust assets held in stock in reform states relative to nonreform states, and (b) the year-toyear change in the percentage of ERISA fund assets held in stock in reform states relative to nonreform states. By adding a further level of differencing, these models should account for additional factors bearing on the asset allocation preferences of the institutions in our sample other than the effect of the new prudent investor rule. The results were largely consistent with the percentage stock models, with a larger effect of the reform (a little over 4 points), and with even stronger evidence of an ongoing, increasing effect over time.

\section{Conclusion}

\subsection{Summary of Results}

Our empirical analysis demonstrates that changes in the default rules of prudent trust investment affected trust portfolio allocation. Depending on the approach taken, our analysis implies that the trust institutions in our sample increased stock holdings by 1.5 to 4.5 percentage points after the adoption of the new prudent investor rule. This is an overall increase in stock holdings of 3 to 10 percent. Our findings, which endure across a variety of identification strategies and numerous robustness checks, explain roughly 10 to 30 percent of the overall increase in stock holdings in the period under study. The rest of the increase appears to be attributable to stock market appreciation.

Assuming that 2 percentage points more of personal trust funds were invested in stock as of 1997, a year when reported personal trust assets totaled nearly $\$ 750$ billion, roughly $\$ 15$ billion more was invested in stock than otherwise would have been. This result is more impressive when one considers that: (1) for many trusts the new law will not require a reallocation; (2) the new law requires the trustee of a noncomplying trust to reallocate the trust portfolio within a "reasonable time" given the tax and other transaction costs of reallocation; (3) the trusts in our sample were held by institutional trustees that tend to have access to competent legal counsel and standard-form trust agreements with well-drafted opt-out provisions; and (4) the data include revocable trusts, which are not likely to be affected by the new rule, and charitable trusts, for which the effect of the new rule is likely to be attenuated. ${ }^{89}$

Percentage of stock holdings is an interesting outcome variable not only because of the old rule's hostility to stock, but also because it proxies for movement along the risk and return curve. Our findings imply movement outward on the risk and return curve after a state's adoption of the new prudent investor rule. The agency problems in trust law, together with trustee compensation schemes, rigid doctrine, and the risk of judicial hindsight bias, combined to make bank trust departments conservative investors under the old law. We cautiously conclude that the new prudent investor rule is welfare enhancing.
${ }^{88}$ The "net percentage stock" robustness check is described more formally in Schanzenbach \& Sitkoff, supra note 12, at 694 \& 699.
${ }^{89}$ See Section 3.1.3. 


\subsection{Implications for Policy, Doctrine, and Future Research}

Our results provide the first empirical evidence that fiduciary law is a potentially viable means of governance in trust law. Although our findings do not speak to the optimal content of trust fiduciary law, they confirm that trustee behavior is sensitive to changes in trust fiduciary law. The fact that fiduciary standards constrain trustees is comforting because the threat of fiduciary litigation is the primary force for minimizing agency costs in the modern trust relationship..$^{90}$

The increasing role of stock in trust portfolios, and the movement of such portfolios outward on the risk and return curve, tend to support reforms allied with the new prudent investor rule such as: (a) formalizing the trustee's duty to diversify; ${ }^{91}$ (b) making less rigid the formal distinction between principal and income; ${ }^{92}$ and (c) measuring damages for imprudent trust portfolio management in relation to a total return benchmark..$^{93}$
Diversification is crucial because, when taking on default risk to reduce inflation risk, firm- and industryspecific (or unsystematic) risk can be avoided, leaving only compensated market (or systematic) risk. Principal and income reform, such as equitable adjustment or unitrust legislation, is necessary to free the trustee's hand to invest for total return without distortion from the duty of impartiality. Such reform is now widespread. ${ }^{94}$ In work now in progress making use of the IRS data referenced earlier, ${ }^{95}$ we examine the effect of the principal and income reforms, both in isolation and in relation to the new prudent investor rule.

Finally, as we will set out in greater detail in future work, measuring damages by reference to total return instead of an interest-rate based remedy will more closely align damages with the injury in fact suffered by the plaintiff. The key point, brought into view by our findings here, is that trust portfolios are now more heavily invested in stock. For such trusts, interestbased remedies will undercompensate in up markets and overcompensate in down markets.
90 See Section 2.1. (2007).

91 See UPIA § 3; Restatement (Third) OF Trusts $\S 90(\mathrm{~b})$

92 See supra note 74.

93 See 4 SCOTT AND AsCHER ON TRUSTS, supra note 67, at $\$ 24.9$;
Dukeminier, SitkofF \& LindgRen, supra note 1, at 709-711; Halbach, supra note 46, at 458-459.

${ }_{94}$ See Restatement (ThiRd) of Trusts (T.D. No. 5, 2009) (Introductory Note to Chapter 23).

${ }_{95}$ See Section 1.2. 


\section{ApPENDIX}

State Prudent Investor Law Reforms

\begin{tabular}{|c|c|c|c|c|c|}
\hline State & $\begin{array}{l}\text { Non-UPIA MPT } \\
\text { Statute }^{96}\end{array}$ & UPIA $^{97}$ & State & $\begin{array}{l}\text { Non-UPIA MPT } \\
\text { Statute }^{96}\end{array}$ & UPIA $^{97}$ \\
\hline Alabama & 1989 & 2007 & Nevada & 1989 & 2003 \\
\hline Alaska & & 1998 & New Hampshire & 1999 & 2004 \\
\hline Arizona & & 1996 & New Jersey & & 1997 \\
\hline Arkansas & & 1997 & New Mexico & & 1995 \\
\hline California & 1987 & 1996 & New York & 1995 & \\
\hline Colorado & & 1995 & North Carolina & & 2000 \\
\hline Connecticut & 1086 & 1997 & North Dakota & & 1997 \\
\hline $\begin{array}{l}\text { Delaware } \\
\text { Florida }\end{array}$ & $\begin{array}{l}1986 \\
1993\end{array}$ & & Ohio & & 1999 \\
\hline Georgia & 1988 & & Oklahoma & & 1995 \\
\hline Hawaii & & 1997 & Oregon & & 1995 \\
\hline Idaho & & 1997 & Pennsylvania & & 1999 \\
\hline Illinois & 1992 & & Rhode Island & & 1996 \\
\hline Indiana & & 1999 & South Carolina & 1990 & 2001 \\
\hline lowa & 1991 & 2000 & South Dakota & 1995 & \\
\hline Kansas & 1993 & 2000 & Tennessee & 1989 & 2002 \\
\hline Kentucky & 1996 & & Texas & 1991 & 2004 \\
\hline Louisiana & & 2001 & Utah & & 1995 \\
\hline Maine & & 1997 & Vermont & & 1998 \\
\hline Maryland & 1994 & & Virginia & 1992 & 2000 \\
\hline Massachusetts & & 1999 & Washington & 1985 & \\
\hline $\begin{array}{l}\text { Michigan } \\
\text { Minnesota }\end{array}$ & 1986 & $\begin{array}{l}2000 \\
1997\end{array}$ & West Virginia & & 1996 \\
\hline Mississippi & & 2006 & Wisconsin & & 2004 \\
\hline Missouri & & 1996 & Wyoming & & 1999 \\
\hline Montana & 1989 & 2003 & & & \\
\hline Nebraska & & 1997 & \multicolumn{3}{|c|}{ Current as of Lexis or Westlaw in Dec } \\
\hline
\end{tabular}

96 We include in this category any statute based on the Restatement (Third) of Trusts or that in comparable language instructs courts to evaluate the prudence of a particular investment in light of the composition of the portfolio as a whole.

97 We include in this category any statute based on UNIFORM PRUdent INVESTOR ACT $\$ 2$ (1994). 